DeVillar: Chinese Scientific Socialism in Global Perspective

$\therefore$

\begin{tabular}{l|l} 
INDIA, CHINA AND AMERICA INSTITUTE \\
1549 CLAIRMONT ROAD, SUITE 202 \\
WWW.ICAINSTITUTE. ORG
\end{tabular}

Chinese Scientific Socialism in Global Perspective:

Geopolitical Implications for Latin America and the United States

Published by DigitalCommons@Kennesaw State University 2009 


\section{Chinese Scientific Socialism in Global Perspective: Geopolitical Implications for Latin America and the United States}

Robert A. DeVillar, Ph.D. Professor, Bagwell College of Education

Kennesaw State University

Journal of Emerging Knowledge on Emerging Markets Volume 1 Issue 1

November 2009

\section{Section I}

\section{Stability and Shift in the Semantics of Socialism: An Overview}

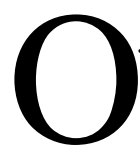

fficial Semantic Continuity: From Marx to Mao to Chinese Modernity

It is evident that from an official Chinese government perspective, capitalism is viewed as a phenomenon that will inevitably yield to global socialism. Yu (2008), a director and research fellow at the prestigious Chinese Academy of Social Sciences, states the case in straightforward language: ${ }^{1}$

\footnotetext{
${ }^{1}$ Yu, Pei (2008). The October Revolution and the historical destiny of scientific socialism: In commemoration of the 90th anniversary of the October Revolution, Social Sciences in China, Vol. 29 , Issue 1, February 2008, pp. 29 - 49. [Yu is Director and Research Fellow of the Institute of World History, Chinese Academy of Social Sciences, Vice President of the China Society of History, and Director of the Research Center of Historical Theory, CASS.]
} 
Deng Xiaoping Theory comes down in one continuous line from Leninism and Mao Zedong Thought and is Marxism in practice with the characteristics of the times and national traits. The magnificent achievements in the development of contemporary Chinese society are the outcome of unwavering adherence to and development of socialism with Chinese characteristics. In the context of economic globalization, we are still living in a transitional time from capitalism to socialism, an era started with the October Revolution. The 21st century will see the rejuvenation of socialism, for the replacement of capitalism by socialism is an inevitable trend of world history.

The above language reflects the sustained belief and rhetoric of historical linearity espoused by the Communist Party of China Central Committee (CPCCC), which spans from the theory of Marx (1848), to its application framed by Lenin's actions and writings and culminating in Russia's October Revolution in 1917, to its national characterization in China by Mao Zedong (1949-1976), and accelerated economic development platform by Deng Xiaoping (1978). As importantly, it faithfully echoes Lenin's belief (written in September 1917/published in April 1918) that the proletariat-socialist world revolution is well on its inevitable way to fruition and triumph over capitalism: ${ }^{2}$

The transition from capitalism to communism is certainly bound to yield a tremendous abundance and variety of political forms, but the essence will inevitably be the same: the dictatorship of the proletariat.

It is important to note that the goal is global socialism not merely country-specific, a theoretical principle consistent with Marx, in his early (pre-1848) writings ${ }^{3}$ and his and Engels' Manifesto of the Communist Party (1848). ${ }^{4}$

\section{Semantic Shifts in the Term Socialism}

The term socialism is insufficient to denote the specific type of political system that is predicted to triumph over capitalism; rather, the term must be accompanied and preceded by the qualifier scientific. This qualifier is necessary for two reasons: first, to differentiate scientific socialism from conservative (including humanistic and various other forms) socialism and, second, to acknowledge, adhere to, and refine through practice the

2 Lenin, V. I. (1918). The state and revolution. Retrieved on April 27, 2009, at http://www.marxists.org/archive/lenin/works/1917/staterev/

3 Tucker, R. C. (1961/2000). Philosophy and Myth in Karl Marx (3 ${ }^{\text {rd }}$ edition). Edison, New Jersey: Transaction Publishers.

4 Panitch, L. (May-June 2009). Thoroughly modern Marx. Foreign Policy, pp. 140-145. See also Burawoy, M. (2000). Guest commentary: Marxism after communism. Retrieved on May 9, 2009, from http://burawoy.berkeley.edu/Marxism/Marxism\%20After\%20Communism.pdf. 
theoretical system advanced by Karl Marx and Frederich Engels in their Manifesto of the Communist Party (1848). Yu (2008) summarizes the nature and importance of this work: ${ }^{5}$

Marx and Engels comprehensively and systematically expounded the theory of scientific socialism in the Manifesto of the Communist Party and pointed out that the communist movement had already become an irresistible historical trend. The publication of the Manifesto marked the official inception of the theoretical system of scientific socialism. Its key idea is that in every historical epoch, the prevailing mode of production and exchange and the social organization necessarily following from it form the basis upon which the political and intellectual history of that epoch is built up.

Proceeding from this fundamental tenet Marx and Engels expounded the historical law of the appearance, development and inevitable extinction of capitalism. (Italics added)

It is equally important to note that the term socialism was insufficiently descriptive by 1848 to convey the type of socialism espoused by Marx and Engels; thus, the term communism was selected by Marx and Engels, as it alone maintained the strict adherence to the abolition of private property. Engels, in the Preface to the 1888 English language edition of the Manifesto, wrote: ${ }^{6}$

By Socialists, in 1847, were understood, on the one hand the adherents of the various Utopian systems: Owenites in England, Fourierists in France, both of them already reduced to the position of mere sects, and gradually dying out; on the other hand, the most multifarious social quacks who, by all manner of tinkering, professed to redress, without any danger to capital and profit, all sorts of social grievances, in both cases men outside the working-class movement, and looking rather to the "educated" classes for support. Whatever portion of the working class had become convinced of the insufficiency of mere political revolutions, and had proclaimed the necessity of total social change, called itself Communist....Thus, in 1847, socialism was a middle-class movement, communism a working-class movement. Socialism was, on the Continent at least, "respectable"; communism was the very opposite. And as our notion, from the very beginning, was that "the emancipation of the workers must be the act of the working class itself," there could be no doubt as to which of the two names we must take. Moreover, we have, ever since, been far from repudiating it.

$5 \quad$ Yu, P. (2008). Op. cit.

6 Mark, K. and F. Engels (1848). Preface to the 1888 English Edition, The Manifesto of the Communist Party. Retrieved on May 1, 2009 at http://www.anu.edu.au/polsci/marx/classics/manifesto.html. 


\section{Semantic Shifts: Capitalism to Imperialism \& Influences on Socialist Thought}

By the late nineteenth and early twentieth centuries, the term capitalism was deemed too narrow by economic analysts to denote the phenomenon of cross-border market extension associated with capitalism's practice. In 1902, this perceived phenomenon characterized by the insatiable appetite and search for new markets beyond a producer's political borders to sell its surplus production that could not be sold in-country was labeled imperialism in the eponymous work by John A. Hobson, an English historian and some time academic. Hobson viewed his study with a sense of urgency rooted in medical metaphors; the study was "distinctively one of social pathology, and no endeavor is made to disguise the malignity of the disease."7 Imperialism was a direct outgrowth of perverted nationalismthat is, nationalism that did not naturally lead to internationalism, or "brotherhood":

Nationalism is a plain highway to internationalism, and if it manifests divergence we may well suspect a perversion of its nature and its purpose. Such a perversion is Imperialism, in which nations trespassing beyond the limits of facile assimilation transform the wholesome stimulative rivalry of varied national types into the cutthroat struggle of competing empires....[Furthermore,] its attack upon the liberties and the existence of weaker or lower races [sic] stimulates in them a corresponding excess of national self-consciousness.... We have welded Africanderdom ${ }^{9}$ into just

7 Hobson, J. A. (1902/2003). Imperialism: A Study. Library of Economics and Liberty. Retrieved on May 1, 2009, at http://www.econlib.org/library/YPDBooks/Hobson/hbsnImp0.html\#Preface.

8 Ibid., Introduction.

9 The term Africanderdom, also spelled Afrikanderdom, here refers to the Jameson Raid, a failed uprising involving a British force entering into the Cape region against Afrikaners (generally, of Dutch origin) in the Transvaal area of what is now South Africa on the New Year's week-end of December 29, 1985 - January 2, 1896. It led, famously, to jingoism and screeds on both sides, and which maligned imperialism and related its consequences to race hatred and thwarted nationalism:

A new feeling has rushed in huge billows over South Africa. The flaccid and cowardly Imperialism, that had already begun to dilute and weaken our national blood, gradually turned aside before the new current which permeated our people. Many who, tired of the slow development of the national idea, had resigned themselves to Imperialism now paused and asked themselves what Imperialism had produced in South Africa? Bitterness and race hatred it is true!

(Quoted in Lord Milner and South Africa, by Ernest Bruce Iwan-Müeller, published by W. Heinemann, 1902. Text quoted was originally published in 1896 in Ons Land, the "organ" of the Afrikander Pary. Digitized version retrieved on May 1, 2009, at http://books.google.com/books?id=JvxyAAAAMAAI). 
such a strong dangerous nationalism, and we have joined with other nations in creating a resentful nationalism hitherto unknown in China [e.g., Boxer Rebellion, Taiyuan Massacre].

Hobson's (1902) analytical framework of imperialism provided an important link to Lenin's pre-revolutionary work, Imperialism, The highest stage of capitalism (1916w/1917p), in the same way that John Stuart Mill's work (1861), Representative Government, Chapter XVI: Of Nationality, as connected with Representative Government, ${ }^{10}$ provided an important link to Hobson's operating definition of the term nation. Mill, in his Autobiography, published in 1873, the year of his death, recalls his continuous exposure and early adherence, beginning in 1829, to the tenets (although not the means) held by the St. Simonian Socialists, particularly respecting community, labor, and the "perfect equality of men and women:",11

But the St. Simonians I continued to cultivate ... Their criticisms on the common doctrines of Liberalism seemed to me full of important truth; and it was partly by their writings that my eyes were opened to the very limited and temporary value of the old political economy, which assumes private property and inheritance as indefeasible facts, and freedom of production and exchange as the dernier mot of social improvement. The scheme gradually unfolded by the St. Simonians, under which the labour and capital of society would be managed for the general account of the community every individual being required to take a share of labour [sic] either as thinker, teacher, artist, or producer, all being classed according to their capacity, and remunerated according to their works, appeared to me a far superior description of Socialism to Owen's. Their aim seemed to me desirable and rational, however their means might be inefficacious; and though I neither believed in the practicability nor in the beneficial operation of their social machinery, I felt that the proclamation of such an ideal of human society could not but tend to give a beneficial direction to the efforts of others to bring society as at present constituted, nearer to some ideal standard. I honoured them most of all for what they have been most cried down for - the boldness and freedom from prejudice with which they treated the subject of family...on which scarcely any reformer has the courage to touch. In proclaiming the perfect equality of men and women, and an entirely new order of things in regard to their relations with one another, the St. Simonians, in common with Owen and Fourier, have entitled themselves to the grateful remembrance of future generations.

10 Mill, J. S. (1861) Representative Government. Retrieved on May 2, 2009, at http://ebooks.adelaide.edu.au/m/mill/john_stuart/m645r/chapter16.html. For a listing of the different schools of Socialism, see http://homepage.newschool.edu/het//schools/utopia.htm. 


\section{From Thought to Action: Russia's Revolution and the Praxis of Early Socialism}

The obvious socio-economic-power gap between the wealthy, the middle class, and the poor, its attendant political structures and consequences, and alternatives posited to remedy it were clearly a passionate issue of socio-intellectual concern, in constant publication and public dialogue and debate, from the time of Jean Jacques Rousseau's foundational notions of collectivism ${ }^{12}$ in his work, Social Contract (1762). This particular work posited other important political notions such as the "abolition of the state/civil society[;]...a] distinction [that] fits with Marx's 'withering away' of the state."13

In October 1917, the intellectual yielded to practice in the form of revolution in Russia, which established it as the first socialist state, ${ }^{14}$ and in short order, Lenin produced decrees that transferred all private land to the people and guaranteed equality and the right to selfdetermination of the people. An important modification Lenin introduced to the dictatorship of the proletariat framework - together with that of shifting the possibility of socialism to pre-capitalist (in more recent terminology, underdeveloped) countries rather than only developed capitalist countries due to imperialism being labeled by Lenin as the highest form of capitalism - was the establishment of a central party to guide the State and educate the proletariat as professional (rather than amateur) revolutionaries: "I assert...that no movement can be durable without a stable organization of leaders...consist[ing] chiefly of persons engaged in revolutionary activities as a profession...to maintain continuity." 15 This principle was placed into action during the first days of the October Russian Socialist Revolution (October 1917) under the name of Council of People's Commissars, with Lenin as its first elected chairman.

As the Chinese Communist Party continues to officially adhere to scientific socialism both locally and globally, it is to Chinese scientific socialism that we now turn for what it may mean for the wider geopolitics of the $21^{\text {st }}$ century, particularly in Latin American and for the United States in that region.

12 Devine, James (June 2000). The Positive Political Economy of Individualism and Collectivism: Hobbes, Locke, and Rousseau. POLITICS \& SOCIETY, Vol. 28 No. 2, pp. 265-304. Sage Publications, Inc. Retrieved on May 3, 2009, at http://myweb.lmu.edu/jdevine/hlr/hlr.pdf.

13 Ibid., p. 290.

14 For information regarding the first successful workers' revolution, see Paris Commune, March 26 -May 30, 1871, at http://www.marxists.org/glossary/orgs/p/a.htm\#paris-commune).

15 Lenin, V. I. (1902). What Is To Be Done? Retrieved on May 5, 2009, at http://www.fordham.edu/halsall/mod/1902lenin.html. 


\section{Section II}

\section{"Socialism with Chinese Characteristics": A Semantico-Political Overview}

\section{Early Semantic Shifts in Chinese Socialism: The Mao Zedong Era}

Nearly four years after the Russian October Revolution, in June 1921, the Chinese Communist Party was formed, and Mao Zedong (1893-1976) was among its initial members. China had, by this time, directly experienced humiliating interactions with European and Asian imperialist powers that had resulted in policies and practices antithetical to China's economic well-being, territorial sovereignty, ${ }^{16}$ and identity-perhaps made largely possible due to China itself concurrently experiencing dynastic deterioration and internal conflict. ${ }^{17}$ Beginning with The Opium War (1839-1842), primarily associated with England, and culminating approximately a century later, this period of the Ch'ing Dynasty involved territorial encroachment by, and political, commercial and civil extraterritoriality and subordination to British, French, German, Russian, the United States and Japanese governments and businesses. Mao and the Chinese Communist Party (as well as other, competing movements such as that of the Chinese Nationalist Party, founded in 1912), therefore, were fully cognizant and experienced in the workings and consequences of imperialism within developing contexts and the devastating effects associated with imperialism to China's governing institutions, economic prosperity, and positive self-image. This period was to be called in China the Century of Shame. Early on, Mao grasped the potential of the Chinese peasantry as revolutionaries and began to organize and train them-a critical and successful strategy supporting the ultimate triumph in 1949 of Chinese socialism over Chiang Kai-shek (1889-1975) and the National Movement he commanded. ${ }^{18}$ Mao's rise to national leadership spans a tumultuous and complex period from 1927 to 1949, in which conflict with the Nationalist movement of Chiang Kai-shek was uppermost

16 "China celebrated the Chinese Youth Day Monday, also the 90th anniversary of an important cultural and political movement in modern Chinese history that fought imperialism and promoted democracy and science ... The 'May Fourth Movement' started with mass student protests on May 4, 1919 against the government's response to the Treaty of Versailles that imposed unfair treaties on China and undermined the country's sovereignty." Reported in China marks 90th anniversary of "May Fourth Movement" reviving patriotism, China View. www.chinaview.cn. Retrieved on May 6, 2009, from http://news.xinhuanet.com/english/2009-05/04/content 11308861.htm.

17 Tait, S. (2006). CHINA: A China Policy for This Century. Hoover Digest, Research and Opinion on Public Policy. Stanford University: Hoover Institution. Retrieved on May 5, 2009, from http://www.hoover.org/publications/digest/2912081.html.

${ }^{18}$ Beeson, M. (2007). Regionalism \& Globalization in East Asia: Politics, security \& economic development. New York: Palgrave Macmillan. 
except during the putative truce reached so both factions could unite to fight Japan's military encroachment into China. ${ }^{19}$ By 1949, Mao had become the chairman of the People's Republic of China and Chiang Kai-shek-in Mao's words, the "running dog" of "U.S. imperialism"20 — and his followers had fled to Taiwan. Until 1945, Taiwan, also known, although not universally recognized, as the Republic of China, had been under Japanese control for fifty years. ${ }^{21}$

Mao's approach to development was based on adapting socialism to the Chinese context, which meant addressing its dominant agricultural base by collectives and, later, communes, ${ }^{22}$ and to supporting "national independence and liberation movements" globally. ${ }^{23}$ By 1955, in the analytic view of one recent analyst, China had "promoted itself as a leader of the developing world, a strategy Beijing is reasserting today." "24 It is widely acknowledged by Western analysts (and Asian-origin analysts publishing in Western academic venues) that Mao's policies, which included the Great Leap Forward (1958-1960) and the Cultural Revolution (1966-1976), failed to develop China's productive capacity in agriculture or manufacturing. ${ }^{25}$

${ }^{19}$ See, for example, Alexander, B. (2002). Chapter 7: Mao Zedong: The winning of China, in How great generals win: A military historian appraises the world's greatest commanders, from Hannibal to MacArthur. New York: W. W. Norton \& Company, pp. 187-208; Schram, S. R. (1989). The thought of Mao Tse-Tung. New York: Cambridge University Press, particularly page 60; Wright, D. C. (2001). The history of China. Westport, Connecticut: Greenwood Publishing Group, particularly pages 135-138.

${ }^{20}$ Mao, Z. (May 30, 1947). The Chiang Kai-shek government is besieged by the whole people. Hsinhua News Agency (China). Retrieved on May 5, 2009, from http://www.marxists.org/reference/archive/mao/selected-works/volume-4/mswv4_20.htm.

${ }^{21}$ Ibid. Note also that Mao was to hold other titles during his tenure, including chairman of the Ninth Communist Party Congress and supreme commander of the nation and army (The Columbia Encyclopedia, Sixth Edition, 2008). His ultimate successor, Deng Xiaoping, held only one: Chairman of the Central Military Commission (Fairbank \& Goldman1998).

22 Meredith, R. (2007). The elephant and the dragon: The rise of India and China and what it means to all of us. New York: W. W. Norton, p.18. Ibid., p.13. 
Tectonic Semantic Shift in Socialism: Deng Xiaoping Lets the Cat Out of the Bag In 1977, following Mao's death in 1976, Deng Xiaoping (1904-1997) was rehabilitated for the third time; in 1978, he was the acknowledged leader of China and held sway over the direction of China's political and economic direction through 1994. Deng's professional development, talents and contributions to China's accelerated socio-economic and political development are complex and beyond the scope of this paper. However, a brief profile will help to situate Deng in the drama of socio-political and economic continuity and change that has characterized China since the early part of the $20^{\text {th }}$ century and will continue for the foreseeable future. Deng was a long-time figure in the Communist Party of China (CPC) leadership, having been initiated into communism during his stay in Paris (1920-1926), receiving further education in Moscow, and returning to China to work within the Communist Party, where he served as chief secretary of the Central Committee by 1927 . He was mentored very early on by Zhou Enlai, and maintained a strong bond with him until Zhou's death in January 1976. Deng became an ally of Mao and formed part of the 6000mile "Long March" (1934-1935) that helped to solidify the communist power base across China. In the war against Japan (1937-1945), Deng proved to be an excellent military leader and administrator-attributes that would serve him well in modernizing China more than three decades later.

During the Cultural Revolution, Deng was "dismissed and purged" by Mao, then rehabilitated in 1972, at which point he served as Vice-Premier. ${ }^{26}$ Beginning in 1973, Deng and Premier Zhou Enlai successfully introduced the notion of comprehensive modernization, which, in January 1975, was expressed more specifically as the "four modernizations"- a 25-year plan for national industrialization through concurrent development of agriculture, industry, science and technology, and national defense-which were complemented by policies of foreign trade, heightened academic standards, and reinviting "scientists and experts" into the institutional fold. ${ }^{27}$ This set of connected, purposeful elements targeting accelerated economic development was officially adopted in December 1978 and "became the framework for the post-Mao period;" state- centralized control at the macro-economic level was combined with local decision-making regarding areas of investment based on perceived returns (profit), complemented by Special Economic Zones to encourage "foreign investment and market liberalization," leading to "an emphasis on light industry and export-led growth." ${ }^{28}$ By allowing farmers to till their designated (state-owned) land - thus ending the practice of collectives — and to sell

26 Yergin, D. and Stanislaw, J. (1998). Commanding Heights. Retrieved on May 7, 2009, from http://www.pbs.org/wgbh/commandingheights/shared/minitextlo/prof dengxiaoping.html.

27
Oden, R. K. (2003). The Deng Xiaoping Era: Assessing its impact on educational and cultural exchanges. Retrieved on May 7, 2009, from http://w3.pku.edu.cn/academic/dxp/pdf/ljk.pdf.

Ibid. 
whatever surplus they produced for profit, Deng immediately and substantially raised rural income levels and initiated "small-scale" industry. ${ }^{29}$

Deng's set of seemingly contradictory practices-from either a socialist or capitalist perspective-were referred to as "socialism with Chinese characteristics;" that is, for some analysts, "land reform, vigorous regional markets, a lively service sector, and local government guidance of local enterprises," 30 and for others, "an attempt on a monumental scale to blend...state ownership and private property, central planning and competitive markets, political dictatorship and limited economic and cultural freedom."31 Deng, universally characterized as a pragmatist, responded to these and similar appeals for clarification with the now ubiquitous aphorism: "It does not matter if a cat is black or white as long as it catches mice." 32 The CCP's relaxation of national economic policies in 1978 unleashed a productivity-creativity force unparalleled in recent human history. Within two decades, as Goldman (1998) summarizes: ${ }^{33}$

China was transformed from an isolated, poor, rural, and politically turbulent country into a relatively open, stable, urbanizing, and modernizing country. With an economy growing at 9 percent a year in the last two decades... China became the fastest-growing economy in the world....In just twenty years, China had evolved from a nation in which roughly six out of ten people lived below the international poverty rate of one dollar a day into a nation in which per capita income virtually quadrupled. It had taken the United States nearly fifty years to double its per capita income in the nineteenth century; it had taken China just a decade.

29 Green, S., Shirk, S., and Zhang, Bin (April 30, 2009). The Stimulus China Needs: Reform the economy to boost consumption. The Wall Street Journal, Opinion Asia. Retrieved on May 6, 2009, from http://online.wsj.com/article/SB124103539101669847.html\#mod=WSJ topics obama?mod= rss topics obama.

30 Fairbank, J. K. and Goldman, M. (1998). China, A new history. Cambridge, MA: The Belknap Press of Harvard University Press.

31 Church, G. J. (January 6, 1986). China. Time. Retrieved on May 6, 2009, from http://www.time.com/time/magazine/article/0,9171,1074879,00.html.

32 Khanna, T. (2007). Billions of entrepreneurs: How China and India are reshaping their futures and yours. Boston, MA: Harvard Business School Press, p. 41. See also, Mahbubani, Kishore (17 September 2008). Why Asia is Rising Now. Speech given at Eminent Speaker's Forum. Retrieved on May 7, 2009, from http://www.adb.org/Knowledge-Management/documents/prof-mahbubanispeech.pdf.

33 Goldman, M. (1998). The post-Mao reform era. In China, A new history (enlarged edition). Fairbank, J. K. and M. Goldman. Cambridge, MA: The Belknap Press of Harvard University Press, p. 406. 
By the quarter-century mark of 2003, companies outside of China had invested more than $\$ 700$ billion in China, and had built "hundreds of thousands of factories nationwide and hired tens of millions of people," who were now earning fives times what they had been prior to the 1978 reform period, and purchasing "cell phones, computers, and even cars and apartments." ${ }^{34}$ With respect to Foreign Direct Investment (FDI) — which, along with perceived economic benefits, is also an indicator of perceived national stability and confidence by foreign investors-China, in 2004, surpassed the United States as the "world's leading destination., ${ }^{, 35}$ From 2002 to 2008, the increase of 185 million people to the Chinese middle class is equivalent to the "entire middle class increase for India (61M), Russia (37M), the U.S. (31M) and all of Europe - combined!" and, by the year 2016, the estimated amount of people in the Chinese middle class (by then, 334M), according to this same source of prediction, will have surpassed the total estimated population of the United States (by then, $314 \mathrm{M}){ }^{36}$ The recent global economic downturn also affected China, diminishing the growth of its Gross Domestic Product (GDP) to 6.1 percent in the first quarter of 2009 for the first time in ten years; however, based largely on the Chinese government's stimulus injection of $\$ 586$ billion, China's projected GDP growth this year is predicted to reach the 8 percent target. ${ }^{37}$

Thus, to apply a single phrase to characterize Deng's transformative role in China's unforeseen and phenomenal economic and political growth, it would be the following: Deng, through his pragmatic, visionary, change-agent leadership, instituted policies and practices that had immediate and lasting results and consequences which influenced the Chinese national context and global economic and environmental contexts alike. The difference between Mao Zedong and Deng Xiaoping is apparent in the qualifier pragmatic,

34 Meredith, R. (2008). The elephant and the dragon: The rise of India and China and what it means for all of us. New York: W. W. Norton \& Company, p. 10.

Devlin, R., Estevadeordal, A., and Rodríguez-Clare, A., Eds. (2006). The emergence of China: Opportunities and challenges for Latin America and the Caribbean. Washington, D.C.: InterAmerican Development Bank, David Rockefeller Center for Latin American Studies, Harvard University, p. xxv.

36 Adler, R. (November/December 2008). Counting on the middle class. In Miller-McClune, Turning research into solutions, pp. 20-23.

37 Roberts, D. (May 18, 2009). China's stimulus goes to work. Business Week, pp. 24-25. In this regard, Kishore Mahbubani (Spring 2009), in his article Can America fail?, published in The Wilson Quarterly (pp. 48-54), remarks on the limitations inherent in behaviors stemming from a continued belief in American exceptionalism: "America's myopia is astounding and incomprehensible. When the stimulus packages of the Chinese and U.S. governments emerged at about the same time, I scanned American publications in search of attempts to compare the two measures. I could not find any. This confirmed my suspicion that American intellectuals and policy-makers could not even conceive of the possibility that the Chinese effort may be smarter or better designed than the American one" (p.52). 
as both men were extraordinary leaders, visionaries and change agents-notwithstanding each having instituted various policies and practices that were seriously flawed and resulted in grave consequences (e.g., Mao's Great Leap Forward and Cultural Revolution; Deng's Tiananmen Square).

\section{Section III}

\section{Bi-Lateral Rifts and Shifts: The Semantics of China and U.S Policy Dynamics}

China, as is evident from the Century of Shame, did not exist in a vacuum during the nineteenth and twentieth centuries. Visits and encroachment by Western institutions and countries to China had been a phenomenon from the late thirteenth century and prevailed to differing degrees until the end of the Second World War. How the United States related to the internal challenges and changes in Chinese political orientations relate as well to later roles that each took within international arenas in which the two governments were present. The Korean War and Vietnam War (known as the American War in Vietnam and China) were two such arenas of bellicose conflict. Latin America is today another, albeit of geopolitical competition through peaceful, commercial and diplomatic means. Thus, an overview of each one's historical policy toward the other is helpful in understanding current events and perspectives involving the two countries within Latin America (discussed in the final section).

The United States' policy toward China in 1941 supported Free China, that is, the Nationalist- (Guomindang) controlled area of China, which co-existed with the Japaneseoccupied area. ${ }^{38}$ The Nationalist were originally led by revolutionary republican Sun Yatsen (1866-1925) during the first quarter of the twentieth century and by Chiang Kai-shek (Jiang Jieshi) from 1927 to 1949—who, as head of the Free China government headquarters in Nanjing, was seen by the United States "as a representative of American ideals." 39 Thus, in fall 1945, the United States "intervened from the beginning [of the Chinese civil war] on the anti-communist side" and supplied the Nationalists even as it officially supported a coalition government comprised of the Communist Party of China and the Nationalist Party. $^{40}$

In spite of U.S. support, Chiang's ineffective leadership and militaristic mind led to burdensome taxation, civilian punishments, hyperinflation, and misdirection of resources to

\footnotetext{
${ }^{38}$ Fairbank and Goldman (1998), op. cit., p. 312

39 Ibid, p. 327.

${ }^{40}$ Ibid, pp. 329, 330.
} 
justify an unpopular civil war-actions which resulted in the disaffection of the general populace, including the wealthy, and ultimately enabled the CPC, with its superior strategies, to triumphantly enter Beijing in January 1949 with Mao Zedong's troops "riding in American trucks led by American-made tanks." ${ }^{41}$ On October 1, 1949, the People's Republic of China was proclaimed, Mao Zedong became President of the Chinese Communist Party/Head of State/Chairman of the Central Committee Military Commission, Zhou Enlai became Prime Minister, and Chiang Kai-shek fled to Taiwan. ${ }^{42}$

During the Cold War (roughly, 1949-1989), China continuously supported Latin American countries in their struggles against both U.S. imperialism ${ }^{43}$ and the perceived danger of a third world war caused by the "competition for hegemony" 44 between the United States and Soviet Union that, by 1950 , was explicitly articulated. ${ }^{45}$ In the 1950 s, the United States "made direct nuclear threats against [China] over Taiwan....more subtle threats over Korea and even Vietnam" 46 -following, in the latter case, the rhetoric-laden policy model of "preventing the Sino-Soviet communist monolith from conquering first Asia and then the world [even though] from the late 1950s on, U.S. intelligence had firm evidence that no such monolith existed," and that, in fact, there had been a "highly exploitable Sino-Soviet split." ${ }^{47}$ China's geopolitical vision for revolution and national liberation movements remained thwarted from the 1950s through the 1970s, when Deng Xiaoping's economic

${ }^{41}$ Ibid., pp. 331-334, 336.

${ }^{42} \mathrm{Li}$, Zhensheng (2003). Red-color news soldier: A Chinese photographer's odyssey through the Cultural Revolution. London: Phaidon Press Limited, p. 312.

${ }^{43}$ See, for example, Grow, M. (2008). U.S. presidents and Latin American interventions: Pursuing regime change in the Cold War. Lawrence, Kansas: University Press of Kansas. Grow describes the continuity of the interventionist policy among U.S. presidents: "All told, six of the nine U.S. presidents who occupied the White House during the Cold War carried out at least one major intervention against a perceived enemy in the Western Hemisphere during their terms in office" ( $p$. $\mathrm{x}$ ). All were justified as deterring socialism, save that of President George H. W. Bush's invasion of Panama, which was a 'war on drugs"' (pp. x-xi). According to Grow's analysis, the factors of "U.S. international credibility, U.S. domestic politics, and lobbying by Latin American and Caribbean actors" - the latter phenomenon described by Geir Lundestad as "intervention by invitation'” (p. xiii)-superseded economic and security factors (p. xi).

${ }^{44}$ Jiang, Shixue (2008), op. cit., p. 29.

${ }^{45}$ McSherry, J. P. (2006). Op cit., p. 197. Specifically, McSherry cites and quotes from the National Security Council Paper No. 68.

${ }^{46}$ Bush, R. C. and O'Hanlon, M. E. (2007), op. cit., p. 154.

47 Gelb, L. H. (May/June 2009). Necessity, choice, and common sense: A policy for a bewildering world, Foreign Affairs, pp. 56-72. Quote from p. 63. 
development vision took precedence, but was delayed until the 1990s due to Latin America's economic downturn during the decade of the 1980s. ${ }^{48}$

Deng Xiaoping's emphasis on pragmatic economic development and opening China to foreign investment "subordinated the revolutionary and anti-imperialist elements of China's foreign policy," while the U.S. and other Western "policymakers concerns... were largely restricted to [China's] nuclear proliferation and arms sales." 49 The effects of Mao Zedong's closure of China and internal policies have been noted earlier, as have the effects of China's opening and pragmatic approach to its economic development and policy of nonintervention beginning with Deng Xiaoping in 1978.

From the late 1990s to 2006, China's competitive need for resources had taken it to countries inside and outside the political comfort zone of the United States, including Darfur, Iran, Myanmar (Burma), North Korea, Uzbek, and Zimbabwe. ${ }^{50}$ China has rethought this strategy in favor of more actively negotiating and participating with the United States and the United Nations toward limiting regimes' actions that transgressed human rights or posed international security threats-although at times vacillating, as it did in the case of Myanmar, or continuing its relationship with countries labeled as "troublesome."

Importantly, as early as 1949, but formalized in December 1953 in Premier Zhou En-Lai's negotiations with India, and extended as a policy vis-à-vis all socialist countries, China had developed, advocated and practiced its Five Principles of Peaceful Co-Existence policy. The website of the Ministry of Foreign Affairs of the People's Republic of China states: ${ }^{52}$

The Five Principles of Peaceful Co-Existence are diametrically opposed to power politics which have been in dominance in international relations over the last few centuries. The Five Principles of Peaceful Co-Existence have become the basic norms in developing state to state relations transcending social systems and

\footnotetext{
${ }^{48}$ Xiang, Lanxin (2008). An alternative Chinese view, in Roett, R. and G. Paz (Eds.), China's expansion into the Western Hemisphere: Implications for Latin America and the United States. Washington, D.C.: Brookings Institution Press. Specific information on pp. 46-48.

${ }^{49}$ Kleine-Ahlbrandt, S. and Small, A. (January/February 2008). China's new dictatorship diplomacy. Foreign Affairs, pp. 38-56.

${ }^{50}$ Kleine-Ahlbrandt, S. and Small, A. (January/February 2008). Op. cit., pp. 41-43.

51 Ibid, pp. 43-51.

${ }^{52}$ Author, China's initiation of the five principles of peaceful co-existence, Ministry of Foreign Affairs of the People's Republic of China. Retrieved on June 1, 2009, at http://www.fmprc.gov.cn/eng/ziliao/3602/3604/t18053.htm.
} 
ideologies. These principles have been accepted by the overwhelming majority of countries in the world.

The five principles are: ${ }^{53}$

mutual respect for each other's territorial integrity and sovereignty (changed to mutual respect for each other's sovereignty and territorial integrity at the AsianAfrican Conference [1955]), mutual non-aggression, non-interference in each other's internal affairs, equality and mutual benefit, ... and peaceful co-existence.

Currently, amidst the continued bilateral cooperation there is also continued tension that demands to be constantly examined, confronted, interpreted and negotiated between the two countries, particularly as China's projected political and economic ascendency continues as the United States experiences dramatic internal economic and institutional instability and downturns. Some analysts, for example, now cite aggregate Western figures to compensate for the lackluster performance of country-specific figures from the United States and compare China's performance and political strength to that framework rather than to a bilateral one. ${ }^{54}$ What to call this economic-political phenomenon also presents analysts with a quandary: Is it scientific socialism, capitalism, or some blend of each? If so, is it tending to move more in one direction that the other; that is, is it leading toward capitalism or socialism? Or, is it its own new paradigm? The economic ascendency model that China has developed is sometimes referred to, perhaps more by non-socialists, as state capitalism, "a system in which the state functions as the leading economic actor and uses markets primarily for political gain." ${ }^{, 55}$ The final section addresses this question within the context of China's presence in Latin America.

\section{Section IV}

\section{China's Scientific Socialism in Latin America: Whither U.S. Capitalism and Hegemony?}

As noted earlier, China's economic development embraced foreign investment and exportdriven growth. As China continued its widespread accelerated growth, so, too, did the need for material resources and markets soar. The aggressive strategy of developing markets and the relentless need to seek resources within and outside of China have been

53 Ibid.

${ }^{54}$ See, for example: Ikenberry, G. John (January/February 2008). The rise of China and the future of the West: Can the Liberal system survive? Foreign Affairs.

${ }^{55}$ Bremmer, I. (May/June 2009). State capitalism comes of age. Foreign Affairs, p. 41. 
complemented - or, alternately, confounded — by cooperative agreements with nations inside and outside the fold of socialism and heightened security concerns by the United States-the latter area of study having adherents on opposite sides of the issue who are referred to pejoratively as "panda sluggers" and "panda huggers." ${ }^{56}$ China's forays into East Asian and African spheres are an example of this developing complex global presence. Worldwide attention — whether political, economic, social or cultural—continues to be increasingly focused on China. However, China's relatively recent presence in Latin America, as investor, partner and purchaser, raises high the flag of hegemonic concern, as this particular region has been closely tied-militarily, politically and economically - to the United States since the Monroe Doctrine was announced in 1823, and is considered, however belittling to Latin America and self-serving of the United States, as its "back yard." 57

This final section addresses China's presence in Latin America, using as its base the points of view of two Chinese scholars, published in 2008 - the one, offering a no-threat-to-U.S.hegemony scholarly perspective; the other, presenting a scenario of caution due to possible geopolitical shifts. Analyses by other writers, from China and Latin America, will complement and inform these two viewpoints. The analysis and interpretation of the two perspectives should result in a particularly cultural and timely understanding of current Chinese geopolitical policies toward Latin America, and the degree to which they are embraced or repudiated by private and government sectors within the United States.

\section{Semantics and Soft Power: China's Latin America and Caribbean Policy}

On November of 2008, China View (which, according to its self-reported description, is "an online news service of Xinhua News Agency...garnering 800 million hits and 80 million page views per day... [a] the top news website in China, and one of the most influential sites in the world") reported that it had printed the full text of the Chinese government's "first ever" policy paper on Latin America and the Caribbean (CPPLAC). ${ }^{58}$ The wording, tone and intent of the policy_-shared and discussed with Latin American leaders prior to its

56 Bush, R. C. and O'Hanlon, M. E. (2007). A war like no other: The truth about China's Challenge to America. Hoboken, NJ: John Wiley \& Sons.

${ }^{57}$ See, for example, Roett, R. and Paz, G. (2008). Introduction: Assessing the implications of China's growing presence in the Western Hemisphere, in Roett, R. and Paz, G. (Editors), China's expansion into the Western Hemisphere: Implications for Latin America and the United States. Washington, D.C.: Brookings Institution Press, p.1; Jiang, Shixue (2008). The Chinese Foreign policy perspective, in Schoultz, L. (1998). Beneath the United States: A history of U.S. policy toward Latin America. Cambridge, MA: Harvard University Press.

${ }^{58}$ Author (November 5, 2008). China's Policy Paper on Latin America and the Caribbean. China View. Retrieved on March 27, 2009, from http://news.xinhuanet.com/english/200811/05/content 10308117.htm. the specific date report was made available on China View as a full text rather than as a link. 
finalization-could not be more different from the historical unilateral, interventionist, ethnocentric, racialist and paternalistic approach of the United States, explicitly articulated in the Monroe Doctrine (1823), the notion of Manifest Destiny, ${ }^{59}$ and American exceptionalism. ${ }^{60}$

The use of rhetoric that assumes and promotes unity among equals and shared interestsregardless of political suasion - therefore, tends to draw in rather than repel, and remains wholly consistent with the Five Principles of Co-Existence policy described earlier. Tellingly, the CPPLAC policy document repeats the terms peace/peaceful and development six times each in its succinctly stated 230 -word Foreword, and directly conveys related terms that reinforce the spirit and intent of working toward common goals in unity, all of which are captured in the Foreword's key sentence: "It is in the fundamental interest of people in all countries and also their common aspiration to share development opportunities, jointly address challenges and promote the noble cause of peace and development of mankind." 61

${ }^{59}$ See, for example, Cleary, M. R. (2008). Explaining the Left's Resurgence, in L. Diamond, M. F. Plattner, and D. Abente Brun, (Eds.), Latin America's struggle for democracy. Baltimore, MD: The John Hopkins University Press, pp. 70-71; Crandall, R. C. (2007). The United States and Latin America after the Cold War. New York: Cambridge University Press, p. xii; Nugent, W. (2008). Habits of empire: A histrocy of American expansion. New York: Alfred A. Knopf, pp. 216ff, 234ff; O’Brien, T. F. (2007). Making the Americas: The United States and Latin America from the age of revolution to the era of globalization. Albuquerque, New Mexico: University of New Mexico Press, pp. 18-49; Scholultz, L. (1998). Beneath the United States: A history of U.S. policy toward Latin America. Cambridge, MA: Harvard University Press, pp. xiv-xv.

${ }^{60}$ Senator Albert Beveridge's statement, recorded in the Congressional Record on January 9, 1900, embodied, according to Lars Schoultz (1998, op. cit., p. 90), his generation's notion of American exceptionalism:

"God has not been preparing the English-speaking and Teutonic peoples for a thousand years for nothing but vain and idle self-contemplation and self-admiration. No! He has made us the master organizers of the world to establish system where chaos reigns. He has given us the spirit of progress to overwhelm the forces of reaction throughout the earth. He has made us adept in government that we may administer government among savage and senile people. Were it not for such a force as this the world would relapse into barbarism and night. And of all our race He has marked the American people as His chosen nation to finally lead in the regeneration of the world. This is the divine mission of America, and it holds for us all the profit, all the glory, all the happiness possible to man. We are the trustees of the world's progress, guardians of the righteous peace."

${ }^{61}$ Author (November 5, 2008), op. cit. 
The specific areas of development include: ${ }^{62}$

1. Political Field (e.g., non-interference; "make the international political and economic order more fair and equitable");

2. Economic Field (e.g., "expand and balance two-way trade;" "achieve common development;" "properly settle trade frictions through consultation and cooperation;" "free trade agreements;" reciprocal investment; promote "Chinese commercial banks to set up branches;" "Cooperation in flora and fauna inspection will be intensified and agricultural trade will be expanded to jointly uphold food security;" industrial cooperation; China "will strengthen practical cooperation ... in transport, information and communications, water conservancy and hydropower and other areas of infrastructure development;" China "wishes to expand and deepen mutually beneficial cooperation ... in resources and energy within bilateral cooperation frameworks;" customs, quality inspection, and tourism cooperation; support of debt reduction and cancellation; economic and technical assistance; promote "South-South cooperation, bringing about a more just and equitable multilateral trading regime and ensuring a bigger say and greater role in decisionmaking;" "deepen its cooperation with chambers of commerce of Latin America and the Caribbean");

3. Cultural and Social Aspects (e.g., cultural and sports exchanges; cooperation in science, technology and education, including "aeronautics and astronautics, biofuel, resources and environment technology, marine technology," among others; "wider application of Chinese technologies on energy-conservation, digital medical treatment, small hydropower and other results of scientific research and advanced applied techniques;" provision of "technical training, services and demonstration;" "mutual recognition of diplomas and academic degrees, and increase the number of Chinese government scholarships;" "vigorously promote exchanges and cooperation in the medical and health care sector ... and share experiences ... in such areas as disease control, response to public health emergencies, and control of HIV/AIDS and bird flu;" "help improve local medical facilities and train local medical professionals;" consular cooperation and personnel exchanges; media cooperation; people-to-people exchanges; cooperation in environmental protection, combating climate change, human resources and social security, disaster reduction/relief and humanitarian assistance, and poverty alleviation);

4. On Peace, Security and Judicial Affairs (e.g., "will actively carry out military exchanges and defense dialogue and cooperation....mutual visits by defense and military officials....provide assistance for the development of the army in Latin

${ }^{62}$ Author (November 5, 2008), op. cit. 
American and Caribbean countries;" including sharing "information on illegal immigration and improve the capacity for its prevention;" "combating terrorism [and other] non-traditional security threats."

\section{Language as a Globally Relevant Cohesive Force: Semantic Convergence?}

The Chinese government's foreign policy language-formally initiated in December 1953 and present in the current CCPLAC policy document - continues to provide the foundation for the cohesive "glue" the form of identification, of being kindred spirits, clearly and locally present in substantive aspects of the global enterprise within which all are engaged. The bonding process has been in place and in action for some 56 years, and its properties appear to be drawing more adherents. This spirit of unity and common purpose, destiny, and interests have been absent from the United States' centuries of geopolitical and commercial strategies and presence in Latin America-where, conversely, the spirit and action of "coercion and military force" have prevailed ${ }^{65}$ and the overall policy profile of the United States has been described as that of a "bad neighbor" 66 manifesting a two-centuries-long ingrained prejudice toward Latin America ${ }^{67}$ that has extended into the post-Cold War "new world order" era. ${ }^{68}$

${ }^{63}$ Currently, China is interested in trade, including the sale of weapons, rather than, say, building up its or others' military as a potential threat to the United States (personal communication, Colonel Eric Rojo, USA Ret., May 11, 2009). The weapons trade may be subsumed under military assistance, as McSherry (2006, p. 202) reminds us: "Under Clinton, U.S. military assistance, as well as equipment and training for Latin America [sic] more than tripled from FY 1996 to 1997. In 1997, the Administration lifted its ban on sales of advanced weaponry and heavy arms to Latin America, in a clear case of complementary military and economic interests." There are more extreme, although highly improbable, scenarios relative to the possibility of armed conflict; see, for example, Bush, R. C. and O'Hanlon, M. E. (2007). A war like no other: The truth about China's Challenge to America. Hoboken, NJ: John Wiley \& Sons. The probability of such scenarios is dampened by the fact of U.S. military expenditures and global presence. In 2008, for example, the military expenditures of the United States accounted for $41.5 \%$ of the world's total military expenditure of $\$ 1.464$ trillion (2005 constant dollars); China, number two in military expenditures "for the first time" in 2008, accounts for 5.8\% of the world's share (Anup Shah [2009, September 9], World Military Spending, Global Issues; retrieved October 24, 2009, at http://www.globalissues.org/article/75/worldmilitary-spending).

${ }^{64}$ Chua, A. (2007). Day of empire: How hyperpowers rise to global dominance-and why they fall. New York: Doubleday.

65 Ibid, pp. 326-344.

${ }^{66}$ Pastor, R. A. (July/August 2008). The future of North America: Replacing a bad neighbor policy. Foreign Affairs, 87(4), p. 85.

${ }^{67}$ Schoultz, L. (1998). Op. cit., pp. 378-379. 
The differential policy approaches extend beyond the merely contrastive or historical. As indicated above, the Chinese policy approach is about creating bonds among communities such that they begin to identify themselves as sharing common values and characteristics with China in order to work together, particularly within a common space-that may indeed be the country itself. The notion of soft power was introduced by Joseph Nye in 1990 in an article he published in Foreign Policy; in 2004, Nye (cited in Kurlantzick, 2007) stated that soft power "rests on the ability to shape the preferences of others.... It is leading by example and attracting others to do what you want." ${ }^{, 69}$ Kurlantzick (2007) posits that the: ${ }^{70}$

Chinese government and many nations influenced by China enunciate a broader idea of soft power... [as it can now mean] anything outside of the military and security realm, including... popular culture and public diplomacy... [and] more coercive economic and diplomatic levers like aid and investment and participation in multilateral organizations.... China can now wield this kind of soft power, and may use it to remake the world....China's new benign image... will help Beijing execute its foreign policy more successfully.

The multifaceted question is what can be expected from China's diverse forays into Latin America, whether through soft power or hard power, particularly insofar as relates to the goals of scientific socialism (or alternate terms Western analysts apply), and what implications might result relative to the traditional hegemony exercised by the United States in this region?

\section{China's Presence in Latin America: Hegemonic Shift or Hegemonic Neutral?}

The first of two Chinese specialists mentioned earlier, Jiang Shixue, ${ }^{71}$ in his 2008 publication acknowledges that Latin America, as a region, has been "traditionally perceived as the backyard of the United States" and states emphatically that "in no way should China's growing presence be interpreted as a challenge to U.S. hegemony in the hemisphere." 72 Yet, identification among states operating to various degrees within the state

${ }^{68}$ McSherry, J. P. (2006). Preserving hegemony: National security doctrine in the post-Cold War era, in Kingstone, P. R. (2006), Readings in Latin American politics: Challenges to democratization. Boston, MA: Houghton Mifflin, pp. 194-205.

${ }^{69}$ Kurlantzick (2007), op. cit., p. 5.

${ }^{70}$ Kurlantzick (2007), op. cit., pp. 6-8.

${ }^{71}$ Chair of the Latin American Studies Department at the Graduate School of the Chinese Academy of Social Sciences (CASS) and deputy director and professor, Institute of Latin American Studies (ILS), in Beijing, China.

${ }^{72}$ Jiang, Shixue (2008), op. cit., p. 28. 
capitalism model —including Mexico, Brazil, Venezuela ${ }^{73}$ — may draw them, and other Latin American and Caribbean countries, together, particularly as "these emerging-market countries only partially embraced free-market principles."74 The preponderant metaphor and ideology of free-market capitalism is that of the "invisible hand;" that of scientific socialism and state capitalism may be termed the "guided hand," where the state-private sector relationship operates in tandem, and, ideally, in efficient and productive synchrony. The U.S. historical "either-or" perspective remains evident toward protecting the free-market ideological model —as defined by the U.S.—against any variation; Bremmer's (May/June 2009), writing in Foreign Affairs, perpetrates this non-negotiable position: ${ }^{75}$

The United States should reassert its commitment to expanding trade both with the European Union.... and with growing economic powers...not least to ensure that these countries do not creep toward state capitalism, thereby adding to the inefficiencies in the global market and limiting U.S. commercial opportunities.

Hedging his bets, however, Bremmer then recommends that the United States should accept sovereign wealth investments from state capitalism countries after a "careful review that they do not compromise U.S. national security." ${ }^{, 76}$ Gelb (May/June 2009, p. 69), on the other hand, states that "If there is anything approaching an ideological battle in the world today, it is between what other states perceive as U.S. unilateralism and their own sense of entitlement." 77

Jiang (2008) writes that China's post-cold war view of the world's trajectory consisted of four elements, including that "hegemonic tendencies would continue ... in particular the United States," ${ }^{, 78}$ that peace and development would be the modus operandi rather than war

${ }^{73}$ Bremmer, I. (May/June 2009), op. cit., pp. 41-47.

${ }^{74}$ Ibid, p. 48.

${ }^{75} \mathrm{Ibid}, \mathrm{p} .54$. The irony of this quote is enhanced by recent and extensive state capitalism practices in the United States, which included saving the banking system, as well as its perennial role in funding the military industrial complex and its periodic practice of corporate socialism. See Ian Bremmer (2009, April 28), Q\&A with Ian Bremmer on State Capitalism, Foreign Affairs at http://www.foreignaffairs.com/discussions/interviews/qa-with-ian-bremmer-on-state-capitalism.

76 Ibid, p. 55.

77 Gelb (May/June 2009), op. cit., p.69.

78 Wood, E. M. (1981, pp. 169-189), in her article Liberal democracy and capitalist hegemony: A reply to Leo Panitch on the task of socialist political theory, published in The Socialist Register (vol. 18), writes: "To say that liberal democracy is 'hegemonic' is to say both that it serves the particular interests of the capitalist class and that its claims to universality have an element of truth.... Capitalist hegemony, then, rests to a significant extent on a formal separation of 'political' and 'economic' spheres which makes possible the maximum development of purely juridical and political freedom and equality without fundamentally endangering economic exploitation (pp. 181). 
and revolution, the world order would be characterized as multi-polar, and that "China and other developing countries would seek to unite in the struggle against an unjust world order in which the rules of the game are determined by the developed nations." 79 The international sanctions brought about by the Tiananmen Square incident and the "uncertainty" of Soviet political viability led to Deng's articulation and dissemination of the "guiding principle of twenty-four characters," namely, as a nation, keep calm in the face of world events, firm in the face of pressure, and confident in the face of difficulties; "keep a low profile, never assume a leadership role, and take action." 80 This included "staying the socialist course in China while continuing to move forward with economic reform." ${ }^{\text {" T1 }}$ The Confucian principle of harmony was officially integrated into China's socialist fabric in the 2006 statement by the Chinese Communist Party (and later expanded to world harmony by President $\mathrm{Hu}$ on the sixtieth anniversary of the establishment of the United Nations): ${ }^{82}$

Social harmony is the intrinsic nature of the socialism with Chinese characteristics and an important guarantee of the country's prosperity, the nation's rejuvenation, and the people's happiness.

China's presence - and integration - into the fabric of Latin American political and economic life extends well beyond the selling and purchasing of goods. It includes having an antidote, through economic diversification, to the United States using its "economic leverage to exert political pressure on China," partnering with Latin America to articulate South-South views on international issues, and establishing long-term and even permanent relationships with political and diplomatic entities, such as the Rio Group, Mercosur, Organization of American States, UN Economic Commission for Latin America and the Caribbean, Latin American Integration Association, Inter-American Development Bank, and Latin American Parliament. ${ }^{83}$ The launching of two satellites jointly by China and Brazil highlighted the effects and potential of South-South cooperation in science and technology, but there are many other areas of cooperation, including "agriculture, forestry, fisheries, animal husbandry, medicine, earthquake prediction, manufacturing, information technology, biology, geology, and aerospace." 84

Retrieved on May 27, 2009, from http://socialistregister.com/socialistregister.com/files/SR 1981 Woods.pdf.

${ }^{79}$ Jiang (2008), op. cit., p. 31.

${ }^{80}$ Ibid, p. 31.

81 Ibid, p. 32.

82 Ibid, pp. 33-34.

83 Ibid, pp. 34-35.

84 Ibid, p. 37. 
Chinese Scientific Socialism in Global Perspective:

Socialist ideology and practices are also at the Latin America's policy-influencing discourse table through the Chinese Communist Party's party-to-party relations with the Socialist International Committee for Latin America and the Caribbean, the São Paulo Forum, the Christian Democrat Organization of America, and the Permanent Conference of Latin American Political Parties, and, importantly, include "ties with more than twenty political parties in ten of the twelve countries that maintain diplomatic relations with Taiwan...in an effort to advance China's diplomatic interests." 85 China's relationship with countries of the Caribbean is characterized by diplomatic and development respect, attention, and high visibility, as well as economic trade ${ }^{86}$ - factors that are uncharacteristic historically and currently of United States' diplomatic profile. As stated earlier, the reaction of the United States through the voices of its specialists and politicians to China's presence in Latin America and other parts of the globe is perhaps in too many cases competitive, distancing, self-serving, jingoistic and even hostile. ${ }^{87}$ This posturing is, in a phrase, archaic, arrogant and alarmist, and will certainly be judged by the global community-as has been the case since the Cold War-as unbecoming of a global leader in a multi-polar world and ill-suited to contributing substantively to its collective needs and vision.

The second of the two specialists reviewed about China in Latin America is Xiang (2008), who acknowledges that the U.S. (Washington, D.C.) has a "growing suspicion that China has a well-thought-out design or grand strategy to undermine the traditional U.S. dominance in the region." ${ }^{88}$ Importantly, Xiang does not agree with this U.S. perspective. Historical and current phenomena that spark perceived kindred spirit affinities include China's and Latin America's colonial/semi-colonial past, their developing country status and challenges,

${ }^{85}$ Ibid, pp. 35-36.

86 Ibid. pp. 36-37.

${ }^{87}$ See James, H. (January/February 2009). The making of a mess: Who broke global finance, and who should pay for it? Foreign Affairs, vol. 88 (1), pp. 162-168; also, Jiang (2008), op. cit., pp. 38-40. Yu (2008, op. cit., p. 43) writes: "in order to maintain its hegemonic position in world trade and production the United States always takes augmenting its military strength as the trump card. American military operations abroad have never ceased since the disintegration of the Soviet Union and the drastic change in Eastern Europe: the invasion of Panama in 1989; the Gulf War from 1990 to 1991; the military intervention in Somali from 1992 to 1993; air raids over the Gulf area from 1998 to 1999; air strikes against Kosovo and Yugoslavia in 1999; the war against Afghanistan in 2001 and the war against Iraq in 2003.

${ }^{88}$ Xiang, Lanxin (2008), op. cit., p. 44. Xiang is a professor of international history and politics at the University of Geneva (Switzerland) and a former Henry Alfred Kissinger Scholar in Foreign Policy and International Relations at the U.S. Library of Congress. Xiang earned his doctorate from the Paul Nitze School of Advanced International Studies of Johns Hopkins University in 1990. Xiang received his B.A. from Fudan University in Shanghai. 
the types of goods that China needs to import and Latin America has for export, and the prospect of sorely needed investment from China to Latin America. ${ }^{89}$ But Chinese policy is driven, according to Xiang (2008), not fundamentally by these qualities or by mere economic development, but by geopolitical factors, stemming from China's lack of acceptance of the "Yalta Treaty's post-war power reconfiguration" and discomfort with the "accompanying Bretton Woods system of a liberal international economic order dominated by the United States and embodied in the International Monetary Fund (IMF) and the World Bank." 90

Latin America, according to Xiang (2008), became salient in the CPC during the late 1980s and early 1990s, as two principles became evident that could well relate to China's own issue of maintaining internal stability within the context of "social shock resulting from economic modernization:" First, "intrinsic social transformation that resulted from democratic electoral process should not be dismissed," and second, the "Pinochet political model - an orderly transition of power from authoritarianism to democracy — [provided] a link between the internal politics of a Latin American country and the political future of the Communist Party of China (CPC)." "91 The phenomenon of "energy politics," and China's subsequent development of "geopolitics research centers," has also added fuel to the suspicions of the U.S. relative to China's presence in Latin America since the late 1990s. ${ }^{92}$ Xiang's (2008) analysis-based perspective on China's Latin American policy over the past three decades leads to a profile-admittedly one that is generated from outside of Chinaof official China as well behind the curve, whether relative to learning, sensitivity, or solidarity, due to its official, long-term, operating penchant for interacting with party, political and organizational elites rather than also embracing those leaders, whether incipient or actual, representing populist sectors. ${ }^{93}$

Currently, China is seeking to maintain its export volume to North America, and particularly the United States, and to invest in manufacturing within Latin America that will sustain its competitive advantage. However, investment in "trade and manufacturing sectors remain small: some 380 firms with $\$ 3$ billion as of 2005, half of which is invested in Venezuela." 94 If the Free Trade Area of the Americas (FTAA) were to materialize, Xiang (2008) predicts that China would be hard pressed to compete with the 30-country grouping,

${ }^{89}$ Xiang, Lanxin (2008), ibid, p. 45.

${ }^{90}$ Xiang, Lanxin (2008), ibid, p. 46

${ }^{91}$ Xiang, Lanxin (2008), ibid, p. 49.

92 Xiang, Lanxin (2008), ibid, p. 50.

${ }^{93}$ Xiang, Lanxin (2008), ibid, p. 51.

${ }^{94}$ Xiang, Lanxin (2008), ibid, p. 53. 
as costs and prices would be competitive, and trade routes and geographic distance an advantage to projected Latin American producers and suppliers. ${ }^{95}$ Nevertheless, for Xiang (2008), present and near-term economic expansion opportunities for China within the Western Hemisphere appear stronger than weaker. In the longer term, China appears to be pinning some of its hopes on the geopolitical shift that would result from the successful integration of Latin America as a unified bloc, along the lines of the Bolivarian Movement spearheaded by Venezuelan president Hugo Chávez, to "move away from the Monroe Doctrine concept [,] reduce the region's dependence on the North American market [,]... [and have China] as an alternative market and partner." 96 This would also place China in a more favorable position for balancing its infrastructure development investments in energy and minerals reserves within Latin America with its subsequent extraction and sale to China, together with agricultural products. ${ }^{97}$ Xiang (2008) sees China's relationship with Latin America as a "neocolonial pattern" and draws a telling, perhaps cautionary, analogy with Britain's past colonial trade pattern in South America-essentially, economic monocultural- or near-monocultural-like export models-which, in China's case, includes soybeans from Argentina, copper from Chile and Peru, and "five primary and agricultural products" from Brazil. ${ }^{98}$

\section{Conclusion}

The presence of China in Latin America (and globally) is a work in progress. Its incipient form, at this point, is perceived or analyzed in multiple ways, most of which result in trying to view with precision a new phenomenon by looking through lenses that need to be refined, if not replaced. For example, in the United States, traditional analyses tend to be reproduced through conservative, neo-conservative, moderate, liberal, or progressive lenses. ${ }^{99}$ Others might use regional lenses that reflect traditional political or economic

\footnotetext{
${ }^{95}$ Xiang, Lanxin (2008), ibid, pp. 53-54.

${ }^{96}$ Xiang, Lanxin (2008), ibid., p. 54.

${ }^{97}$ Xiang, Lanxin (2008), ibid, p. 55.

${ }^{98}$ Xiang, Lanxin (2008), ibid, p. 55.
}

${ }^{99}$ See Deudney, D. and Ikenberry, G. J. (January/February 2009). The myth of the autocratic revival: Why liberal democracy will prevail. Foreign Affairs, vol. 88(1), pp. 77-93. The authors' base their analysis on the lens through which they perceive China (and Russia), that is, one of authoritarian capitalism, rather than scientific socialism. Thus, they conclude that the policy of the United States (and other "liberal democracies") should integrate "nondemocratic" states in international institutions based on the premise that autocratic capitalism will inevitably yield to liberal democratic capitalism. To opt for non-integration-exclusion-would "worsen relations and reinforce authoritarian rule" (p.93). The premise characterizes the notion of hegemonic liberalism (see footnote 76 above). 
analyses emanating from Africa, Asia, Europe, Latin America, the Middle East-or one country's or region's analysis, whether comparative or contrastive, of a region outside its own. The analyses cum rhetoric of many U.S. political and economic analysts regarding China's global, regional or national activities send the same, tired Cold War-type "us versus them" messages and reflect those same scenarios of potential threat and destruction. ${ }^{100}$ More market-driven analysts might favor the reality of competitive trade, but are no more able to gauge the effects of China's national development or expansionist needs and what effects they may have on the United States and other countries. Chinese analysts are able to situate China within historical and current contexts, from national to global, but differ regarding the implications of China's current extraordinary geopolitical position or ambitions. Economic analyses - trade figures, comparative country figures, etc.- - are interesting but do not lift the veil on the trend toward any particular political or economic shift or model.

Scientific socialism, under the Communist Party of China's leadership, particularly over the past thirty years, has produced its own prism, and is producing a dramatic spectrum of new waves and distributions, emanating colors beyond red. To objectively view, analyze and interpret these complex phenomena, analysts must first gain access to, and learn to appropriately use, lenses that transcend their particular ideology. Yu (2008, p. 47) situates "socialism with Chinese characteristics" ideologically: ${ }^{101}$

There are fundamental differences between socialism with Chinese characteristics and democratic socialism in whether or not upholding the guidance of Marxist theory, the communist objective, the dominant position of public ownership of the means of production or the democratic dictatorship of the people. Drawing a clear line of demarcation between the two means drawing a clear line of demarcation between Marxism-Leninism and anti-Marxism-Leninism and between socialism and capitalism. This is of great significance for us as we look at the downfall of the Party and the state in the former Soviet Union and maintain the leading position of Marxism in the ideological field.

Missing, then, is an analytical perspective to capture potentially new forms emanating from the scientific socialist prism. A perspective or spate of perspectives that, first, may identify and scrutinize, however tentatively, the various dimensions associated with the neo-rhetoric and reach of globalization - that is, how Chinese scientific socialism has interacted with institutions and populations, as well as with unprecedented historical dynamics, within its national context and outside of its national borders to create a new prism and produce new waves. Secondly, an analytical perspective must capture the degree to which this unique phenomenon is economically-, socially- and politically-viable in producing globally beneficial strategies, actions and well-distributed outcomes.

100 James, H. (January/February 2009), op. cit., p. 163.

101 Yu, Pei (2008), op. cit., p. 47. 
Chinese Scientific Socialism in Global Perspective:

The China-Latin America-United States triangle remains in the making and its future form uncertain. However, the fact that it is under construction is unquestioned. The variables that are in place are many and their weight unknown. Will there be a South American oil cartel, a Free Trade Area of the Americas, a new and improved U.S.-Mexico-Canada arrangement, an integrated South America, a distancing from or moving toward the U.S., a Latin American trend toward state capitalism? Will China's party-to-party diplomacy lead to a spirit of camaraderie that the U.S. has never been able to develop, much less enjoy? All is speculation at this point, however well-based on facts and figures.

China does appear to speak a language that communicates and resonates nationally and globally, in no small part due to its claim to having or to having a socially-grounded, egalitarian foundation, complemented by the presence or prospects of substantive Chinese external investment directed at relevant economic development that extends beyond its current political boundaries. On the other hand, the United States, however unjustifiably, is being profiled and measured as, alternately, an also-ran, a dark horse or a defending champion-but not as the clear winner or even top contender. China has taken pains over generations to establish itself as a nation, as a people, as a world player. It looked inward and produced a rhetoric that reflects principles of unity that, I argue, in most cases can reflect those upon which democracies are founded. The defining difference between China and the United States is that, respectively, the group is the unit of analysis rather than the individual. $^{102}$

China now shares more amply its rhetoric and communicates internationally that for all to prosper it needs and seeks others with whom to share opportunities, markets, investments, development, and power. It is a rhetoric that fits the times. And the practices that relate to it have to this point resulted in gains that are at once spectacular, widespread and, particularly given the present economic climate, unique in productivity, however environmentally degradative. To what degree this rhetoric and practice also reflects the philosophy of scientific socialism or a substantive trend toward the application of what is termed scientific socialism within China or beyond its borders remains unclear. ${ }^{103}$ What is clear is that,

102 Wood, E. M. (1981, op. cit., p. 187) differentiates between liberalism and democracy, stating that the former alienates power "in order to permit fundamentally individualistic human beings to occupy themselves with private concerns."

${ }^{103}$ Lanxin Xiang's (2006, Sunday, April 16; p. B03) quote illustrates this state of ambiguity (Why

Washington Can't Speak Chinese. The Washington Post). Retrieved on June 4, 2009, at

http://www.washingtonpost.com/wp-

dyn/content/article/2006/04/14/AR2006041401896.html?sub=AR:

As China's economic strength grows, no one, not even the Chinese ourselves, can prevent China's influence from spreading into politics, values and ideology. It is in those arenas that conflicts with the United States can arise, and unfortunately, it is precisely in those areas that misunderstandings between the two nations run rampant.... Washington's policy elites hardly deserve all the blame for the lack of mutual understanding. For a long time, Chinese leaders have been incapable of explaining China to the outside world. When the Chinese invent a 
whatever its name, over the past thirty years and for the foreseeable future, it is working better than the traditional capitalist rhetoric and practice.

foreign policy theme, they often deploy coded language that leads to more confusion than clarity on the international front. 